\title{
The influence of farming system elements on the yield of barley in the forest-steppe zone of the Trans-Urals ${ }^{*}$
}

\author{
N.A. Feoktistova ${ }^{1}$, and D.V. Eremina ${ }^{2, *}$ \\ ${ }^{1}$ Federal State Institutes Federal Research Center Tyumen Scientific Center of Siberian Branch of the \\ Russian Academy of Sciences (Tyumen Scientific Center SB RAS), Tyumen, Russia \\ ${ }^{2}$ Federal State Budgetary Educational Institution of Higher Education State Agrarian University of the \\ Northern Trans-Urals, Tyumen, Russia
}

\begin{abstract}
The results of long-term stationary studies on the influence of farming system elements on the yield of spring barley in the forest-steppe zone of the Trans-Urals are presented. In the experiment, the role of the precursor; the main tillage (plowing and surface scarification); three levels of mineral nutrition were studied. The variation of the barley harvest for 2004-2014 under the influence of weather conditions that have direct and indirect impact on the formation of the yield of cereals is shown. The yield of barley primarily depends on the level of mineral nutrition. The average yield of barley sown after peas was $3.52 \mathrm{t} / \mathrm{ha}$, with a variation in the range of 2.40-4.24 t/ha. In the variant where the precursor was oat, the yield of barley was $3.39 \mathrm{t} / \mathrm{ha}$ with a variation from 2.11 to $4.72 \mathrm{t} / \mathrm{ha}$. The share of the contribution of the growing season weather conditions is $49 \%$ (the precursor is peas) and $72 \%$ (the precursor is oat). The minimum yield over the years of research was $1.44 \mathrm{t} / \mathrm{ha}$ on the variant where the precursor was oat, fertilizers were not applied, and the main tillage was surface scarification. The maximum yield was $5.57 \mathrm{t} / \mathrm{ha}$ on the variant with a dose of fertilizers $\mathrm{N}_{54} \mathrm{P}_{52} \mathrm{~K}_{52} \mathrm{~kg} / \mathrm{ha}$, which were introduced by plowing.
\end{abstract}

\section{Introduction}

Western Siberia belongs to the zone of risky agriculture not only because of cold and long winters, but also because of the variability of the growing season weather conditions. In Siberia, summer is often hot and dry, and autumn is cold and rainy [1,2]. Frequent late spring frosts and early snowfall, until now, reduce the productivity of arable land, and in some years they cause the complete death of sowings. Exactly for this reason the agriculture on an industrial scale in Siberia began to develop relatively recently. The lack of adapted varieties, animal breeds, imperfect system of fertilizers and plant protection caused low yields that could only meet local needs $[3,4,5]$. Nevertheless, in the XX century, with the development of agricultural science, new varieties of grain crops were created, elements of plant cultivation technology were studied and developed, considering the soil and

\footnotetext{
* Corresponding author: soil-tyumen@yandex.ru
} 
climatic conditions of the region $[6,7,8]$. This became the starting point for the large-scale development of the agro-industrial complex in Western Siberia. In recent decades, with the advent of computer technology, agriculture has entered a new stage of development increasing the productivity of arable land through the introduction of new technologies and optimization modeling of technological processes $[9,10,11]$. The introduction of digital technologies allowed to begin the process of studying the influence of each factor on a separate element of the farming system, which in the near future will make it possible to use the bioclimatic potential of Siberia as efficiently as possible.

The productivity of agrocenoses depends on soil and climatic conditions and elements of the farming system, the main of which are the following: the precursor, the level of mineral nutrition, soil cultivation and plant care. By the nature of the manifestation, weather conditions are not only uncontrolled, but also limiting the yield of agricultural crops. Despite the breakthrough technologies in the agro-industrial complex, people have learned only to consider the peculiarities of the climate and to react relatively quickly to adverse weather conditions. Until the beginning of the XX century, soil fertility was also uncontrolled, which led to the differentiation of the country's regions by yield, and later the stratification of society by socio-economic factor. In the XX century, with the development of science and technology, technologies that allow to change soil fertility become available to farmers. The most accessible was the change in the nutritional regime of arable land with the help of mineral fertilizers and various meliorants $[12,13]$. Therefore, soil conditions that were previously considered as an uncontrolled factor are now classified as controlled one.

The combination of unfavorable natural factors in the conditions of Western Siberia reduces the productivity of arable land by $50-70 \%$. Scientific and technical solutions expressed in the selection of tillage system, mineral fertilizers, varieties and means of protection can reduce negative natural factors by $20-30 \%$, thereby increasing yields in the zone of risky farming. This determines the relevance of the development of new technologies and the creation of varieties of grain crops that provide a certain compensation for the influence of limiting factors by using the genetic potential of agricultural crops.

The relevance of this issue is expressed by the fact that the combined influence of soilclimatic and farming system elements in Western Siberia has not been sufficiently studied. Recently, there have been works on the study of individual elements of soil cultivation, fertilizers and crops, but they did not study the combined effect of controlled and uncontrolled factors.

The purpose of this work is to study the contribution of natural and anthropogenic factors in the formation of yield of cereals in Western Siberia.

\section{Objects and methods of research}

Studies on the influence of various factors on cereals were conducted at the experimental field of the Research Institute of Agriculture of the Northern Trans Urals - branch of the Tyumen Scientific Center, which is located in the northern forest-steppe zone of Western Siberia.

The soil is dark gray forest podzolized, heavy loamy formed on the cover carbonate loams. The depth of calcium carbonate varies from 90 to $120 \mathrm{~cm}$. According to the agrochemical properties, the soil of the experimental field is typical for Western Siberia. The humus content in the arable layer is $4.4 \%$, with a nitrogen content of $0.14 \%$. The distribution of humus over the soil section is sharply decreasing, characteristic of the type of gray forest soils [14]. The content of phosphorus and potassium in the humus layer reaches 0.14 and $0.13 \%$, respectively. The soil of the experimental field is slightly acidic, 
the exchange acidity is 5.1 units, with a significant variation in hydrolytic acidity in the range of 3.0-5.2 $\mathrm{mmol}(\mathrm{eq}) / 100 \mathrm{~g}$ of soil.

According to its physico-chemical properties, the dark gray forest soil is not inferior to the chernozems of Western Siberia. The amount of absorbed bases varies slightly from 20 to $24 \mathrm{mmol}(\mathrm{eq}) / 100 \mathrm{~g}$ of soil, with a degree of saturation with bases of $80-82 \%$ of the cation exchange capacity.

The content of mobile phosphates in the arable horizon before experiment establishment was $60 \mathrm{mg} / \mathrm{kg}$ of soil, which corresponded to a very low supply of plants with this nutrition element. The availability of mobile potassium was also very low for cereals $-90 \mathrm{mg} / \mathrm{kg}$ of soil.

The experiment was established according to a three-factor scheme using the method of split plots. Factor A is the precursor (peas, oat); factor B is the main tillage (plowing, surface scarification); factor $\mathrm{C}$ is the level of mineral nutrition.

Two stationary field crop rotations were taken as a test site, which are deployed in space and in time. The first crop rotation is grain-fallow, with alternating crops: black fallow spring wheat - spring wheat - peas - barley. The second crop rotation is grain-grass (barley with clover sowing) - clover of the first year of use - clover of the second year of use spring wheat - oat. The selected crop rotations belong to various ecobiological directions, but the presence of two fields of perennial legumes in the grain-grass crop rotation is equivalent to such a precursor as peas. Therefore, it can be argued that the studied precursors to a certain extent approach each other in terms of efficiency.

The studies were conducted in the period from 2004 to 2014. The object of research: spring barley, which was sown with two precursors - peas and oat. In the experiment, varieties zoned in the Tyumen region were sown: in the period from 2004 to 2010, the Odesskiy 100 variety was used; from 2011 to 2014, the Acha variety was used.

Two main mechanical tillages were used for barley - plowing with a plow PN-4-35 to a depth of 20-22 cm and surface scarification KPE-3.8 to a depth of 10-12 cm. The main tillage was carried out in the autumn period, immediately after the cleaning of the precursor.

Different levels of mineral nutrition were created by applying different doses of mineral fertilizers $\left(\mathrm{N}_{37} \mathrm{P}_{34} \mathrm{~K}_{34} \mathrm{~N}_{54} \mathrm{P}_{52} \mathrm{~K}_{52}\right)$. A natural agricultural background (without fertilizers) was used as a control. Ammonium nitrate and diammophoska were introduced into the soil by cutting in with a grain seeder in the spring period. The depth of fertilization was $8-10 \mathrm{~cm}$.

To determine the contribution of random and controlled factors, the calculation algorithm "EXCEL add-in for agricultural statistics" was used [15]. The standard procedure of variance analysis was carried out - the average values of the trait in each of the aggregates were calculated, the value of the F-criterion and the smallest significant difference were found.

\section{Results and discussion}

Weather conditions during the years of research played an important role in the formation of yield and had a direct impact on the effectiveness of barley cultivation technology elements. The yield variation was largely determined by hydrothermal conditions, which act both directly and indirectly $[16,17]$.

Our research has shown that the weather conditions of the growing season (MayAugust) in the northern forest-steppe of Western Siberia vary quite widely. From 2004 to 2014, the sum of temperatures above $10^{0} \mathrm{C}$ varied from 1696 to 2132 degrees. Nevertheless, the variation coefficient, which was equal to $7 \%$, indicates minor fluctuations, which allows to apply the average value for the region - 1984 degrees. 
The next climatic indicator, which is an uncontrolled factor, is the amount of precipitation that fell during the growing season. In the northern forest-steppe of the TransUrals, it varied in the years of research from 98 to $349 \mathrm{~mm}$. The coefficient of variation was $28 \%$, which indicates a very high degree of variability.

The total climate indicator is the Selyaninov hydrothermal coefficient (HTC), which takes into account temperature and precipitation. Our calculations showed that in the period from 2004 to 2014 HTC in the experimental field varied from 0.5 to 1.9 units, which indicates the presence of arid and excessively moist growing seasons. The coefficient of variation was $30 \%$, which indicates a very high degree of indicator variability in the northern forest-steppe of the Tyumen region.

The weather conditions of the growing season have a certain impact on the yield of agricultural crops. Our studies have shown that the barley yield depends to a minimum extent on the sum of temperatures above $10^{0} \mathrm{C}$ - correlation coefficient is $0.2-0.3$ units, which corresponds to a weak coupling force. The effect of precipitation on yield is higher than that of temperature. The northern forest-steppe of Western Siberia is characterized by an inverse relation, unlike the European part of Russia. In our experiments, the correlation coefficient was-0.4-0.5 units, which corresponded to the average dependence of the crop on the precipitation of the growing season. The relation between the hydrothermal coefficient and barley yield in the experimental field was also average $(r=-0.4-0.6)$.

Table 1. Influence of hydrothermal conditions on barley yield in the forest-steppe of the Trans-Urals, $\mathrm{t} / \mathrm{ha}$ (control, without fertilizers).

\begin{tabular}{|c|c|c|c|c|c|c|c|c|c|c|c|}
\hline \multirow[t]{3}{*}{ Years } & \multirow{3}{*}{$\begin{array}{l}\text { Sum of } \\
\text { tempera } \\
\text { tures } \\
>10>^{0} \mathrm{C} \\
\text { for the } \\
\text { growing } \\
\text { season }\end{array}$} & \multirow{3}{*}{$\begin{array}{l}\text { Precipi } \\
\text { tation } \\
\text { amoun } \\
t, \mathrm{~mm}\end{array}$} & \multirow[b]{3}{*}{$\begin{array}{c}\text { HT } \\
\text { C }\end{array}$} & \multicolumn{8}{|c|}{ Precursors } \\
\hline & & & & \multicolumn{4}{|c|}{ Peas } & \multicolumn{4}{|c|}{ Oat } \\
\hline & & & & $\min$ & $\max$ & $\begin{array}{c}\text { aver } \\
\text { age }\end{array}$ & $\begin{array}{c}\mathrm{Cv}, \\
\%\end{array}$ & $\min$ & $\max$ & & $\begin{array}{c}\mathrm{Cv}, \\
\%\end{array}$ \\
\hline 2004 & 2125 & 271 & 1.3 & 2.77 & 3.14 & 2.40 & 15 & 1.84 & 2.65 & 2.11 & 20 \\
\hline 2005 & 1991 & 213 & 1.1 & 3.35 & 4.17 & 3.82 & 11 & 2.78 & 3.63 & 3.45 & 13 \\
\hline 2006 & 1885 & 349 & 1.9 & 2.67 & 3.67 & 3.53 & 15 & 2.34 & 3.21 & 2.75 & 16 \\
\hline 2007 & 2132 & 295 & 1.4 & 3.04 & 3.74 & 3.51 & 10 & 3.05 & 3.57 & 3.33 & 8 \\
\hline 2008 & 1696 & 285 & 1.7 & 1.95 & 3.11 & 2.52 & 23 & 2.07 & 2.54 & 2.37 & 10 \\
\hline 2009 & 1895 & 182 & 1.0 & 3.16 & 3.92 & 3.86 & 11 & 3.13 & 4.04 & 3.68 & 12 \\
\hline 2010 & 2100 & 212 & 1.0 & 2.98 & 3.74 & 3.57 & 11 & 4.24 & 4.98 & 4.72 & 8 \\
\hline 2011 & 1895 & 225 & 1.2 & 3.04 & 4.12 & 3.99 & 15 & 3.35 & 4.25 & 3.98 & 12 \\
\hline 2012 & 1995 & 98 & 0.5 & 3.22 & 3.87 & 3.77 & 9 & 3.07 & 4.00 & 3.63 & 13 \\
\hline 2013 & 2008 & 262 & 1.3 & 3.35 & 4.11 & 3.78 & 10 & 2.81 & 3.66 & 3.46 & 13 \\
\hline 2014 & 2100 & 251 & 1.2 & 3.91 & 4.52 & 4.24 & 7 & 3.18 & 3.95 & 3.78 & 11 \\
\hline
\end{tabular}

In some years of research, there was a significant variation in barley yield - the variation coefficient reached $23 \%$ (2008) on the peas as precursor and $20 \%$ (2004) on the variant where barley was sown after oat. The maximum barley yield on repetitions in the years of research was 3.11-4.52 t/ha after peas and 2.54-4.98 t/ha after oat. This fact indicates the absence of a serious advantage of peas as a precursor for barley. The cumulative effect of the elements of barley cultivation technology is better considered by the average yield data for years of research. 
The average barley yield on the natural agricultural background for dump tillage was 3.39-3.52 t/ha (Table 2). No special advantages of peas and oat, as precursors, were found. However, in some years, the sowing of barley after oat was characterized by a wide range of yields $-2.11-4.72 \mathrm{t} /$ ha with a variation coefficient of $22 \%$. The refusal of plowing in favor of surface scarification steadily reduces the yield of barley with any precursor. The yield range in areas with surface scarification was 1.44-4.54 t/ha with a variation coefficient of $33 \%$. The variability of the yield of barley grown after peas was lower $(\mathrm{Cv}=22 \%)$. The role of the precursor in the formation of the barley yield in the forest-steppe of the TransUrals was minimal - the effect was $1.7 \%$. This proves that there is no advantage of peas as a precursor, relative to oat.

Table 2. Barley yield depending on the precursor, the main tillage and the level of mineral nutrition (2004-2014), t/ha.

\begin{tabular}{|c|c|c|c|c|c|c|}
\hline \multirow{2}{*}{ Precursors } & \multirow{2}{*}{$\begin{array}{l}\text { Main tillage } \\
\text { type }\end{array}$} & \multirow{2}{*}{$\begin{array}{l}\text { Level of } \\
\text { mineral } \\
\text { nutrition }\end{array}$} & \multicolumn{3}{|c|}{ Yield, t/ha } & \multirow{2}{*}{$\mathrm{Cv}, \%$} \\
\hline & & & average & $\min$ & $\max$ & \\
\hline \multirow{6}{*}{ Peas } & \multirow{3}{*}{ Plowing } & Control & 3.52 & 2.40 & 4.24 & 16 \\
\hline & & $\mathrm{N}_{37} \mathrm{P}_{34} \mathrm{~K}_{34}$ & 4.04 & 2.61 & 4.79 & 15 \\
\hline & & $\mathrm{N}_{54} \mathrm{P}_{52} \mathrm{~K}_{52}$ & 4.40 & 2.95 & 5.25 & 15 \\
\hline & \multirow{3}{*}{$\begin{array}{c}\text { Surface } \\
\text { scarification }\end{array}$} & Control & 3.00 & 1.58 & 3.81 & 22 \\
\hline & & $\mathrm{N}_{37} \mathrm{P}_{34} \mathrm{~K}_{34}$ & 3.62 & 2.10 & 4.39 & 19 \\
\hline & & $\mathrm{N}_{54} \mathrm{P}_{52} \mathrm{~K}_{52}$ & 4.06 & 2.34 & 4.62 & 16 \\
\hline \multirow{6}{*}{ Oat } & \multirow{3}{*}{ Plowing } & Control & 3.39 & 2.11 & 4.72 & 22 \\
\hline & & $\mathrm{N}_{37} \mathrm{P}_{34} \mathrm{~K}_{34}$ & 4.00 & 2.37 & 5.13 & 21 \\
\hline & & $\mathrm{N}_{54} \mathrm{P}_{52} \mathrm{~K}_{52}$ & 4.35 & 2.54 & 5.57 & 19 \\
\hline & \multirow{3}{*}{$\begin{array}{c}\text { Surface } \\
\text { scarification }\end{array}$} & Control & 2.92 & 1.44 & 4.54 & 33 \\
\hline & & $\mathrm{N}_{37} \mathrm{P}_{34} \mathrm{~K}_{34}$ & 3.56 & 1.85 & 5.38 & 32 \\
\hline & & $\mathrm{N}_{54} \mathrm{P}_{52} \mathrm{~K}_{52}$ & 3.89 & 2.37 & 5.42 & 27 \\
\hline
\end{tabular}

The variance analysis of the three-factor experiment (precursor (factor A); main tillage (factor B); fertilizers (factor C)) showed that the maximum effect is exerted using mineral fertilizers - the share of the contribution to yield is $72 \%$. With an increase in the level of mineral nutrition, the variation in barley yield and the range of values (max-min) decreases. The maximum yield was obtained at a high agricultural background $\left(\mathrm{N}_{54} \mathrm{P}_{52} \mathrm{~K}_{52}\right)$, when using plowing $-5.25 \mathrm{t} / \mathrm{ha}$ after peas; $5.57 \mathrm{t} / \mathrm{ha}$ after oat. The interaction of the studied factors $(\mathrm{AB} ; \mathrm{AC} ; \mathrm{BC}$ and $\mathrm{ABC})$ was not proven - the $\mathrm{F}$ fact was less than $\mathrm{F}_{\text {tabl. }}$.

The productivity of agrocenoses, as noted earlier, depends on the elements of crop cultivation technology, as well as on weather conditions. It should be noted that uncontrolled factors (temperature, precipitation) have not only a direct impact on the growth and development of plants, but also can enhance the effect of technological operations. Moreover, in one direction or another. Therefore, when calculating the share of the contribution of the regulated factor, it is necessary to analyze their interaction with the weather conditions of a particular year. Table 3 shows the results of a three-factor analysis of the variance of barley yield, where factor C (years) is present. As can be seen from the table, the influence of this factor for Western Siberia is very high $-49 \%$ (the precursor is peas); $72 \%$ (oat). Therefore, when predicting the efficiency of cultivation of agricultural crops, it is necessary to base on the weather conditions of the region.

Table 3. Results of three-factor variance analysis of barley yield (precursor - peas).

\begin{tabular}{|l|l|c|l|l|l|l|}
\hline Source of variation & $\begin{array}{c}\text { Sum of } \\
\text { squares }\end{array}$ & $\begin{array}{c}\text { Degrees } \\
\text { of }\end{array}$ & Variance & Ffact & Ftab 095. & Effect \% \\
\hline
\end{tabular}




\begin{tabular}{|c|c|c|c|c|c|c|}
\hline & & freedom & & & & \\
\hline \multicolumn{7}{|c|}{ Precursor - peas } \\
\hline Factor A (main tillage) & 5.3 & 1 & 5.3 & 61 & 4.0 & 6 \\
\hline $\begin{array}{l}\text { Factor B (mineral } \\
\text { nutrition level) }\end{array}$ & 22.3 & 2 & 11.1 & 127.2 & 3.1 & 25 \\
\hline Factor C (years) & 44.6 & 10 & 4.5 & 50.9 & 2.0 & 49 \\
\hline $\begin{array}{r}\text { Interaction of factors: } \\
\mathrm{AB}\end{array}$ & 0.5 & 2 & 0.3 & 3.1 & 3.1 & 1 \\
\hline $\mathrm{AC}$ & 1.2 & 10 & 0.1 & 1.3 & 2 & 1 \\
\hline $\mathrm{BC}$ & 7.7 & 20 & 0.4 & 4.4 & 1.7 & 9 \\
\hline $\mathrm{ABC}$ & 3.2 & 20 & 0.2 & 1.8 & 1.7 & 4 \\
\hline \multicolumn{7}{|c|}{ Precursor - oat } \\
\hline Factor A (main tillage) & 5.8 & 1.0 & 5.8 & 364.6 & 4.0 & 5 \\
\hline $\begin{array}{l}\text { Factor B (mineral } \\
\text { nutrition level) }\end{array}$ & 21.3 & 2.0 & 10.7 & 673.9 & 3.1 & 17 \\
\hline Factor C (years) & 92.5 & 10.0 & 9.2 & 584.7 & 2.0 & 72 \\
\hline $\begin{array}{r}\text { Interaction of factors: } \\
\mathrm{AB}\end{array}$ & 0.0 & 2.0 & 0.0 & 0.1 & 3.1 & 0 \\
\hline $\mathrm{AC}$ & 4.1 & 10.0 & 0.4 & 26.0 & 2.0 & 3 \\
\hline $\mathrm{BC}$ & 3.4 & 20.0 & 0.2 & 10.7 & 1.7 & 3 \\
\hline $\mathrm{ABC}$ & 0.9 & 20.0 & 0.0 & 2.8 & 1.7 & 1 \\
\hline
\end{tabular}

The advantage of plowing and surface tillage was not revealed. This factor (A) has a minimal effect $-5-6 \%$ in the formation of the barley yield. The reason for this is the almost identical water regime and the difference in productive moisture reserves in the soil, which is formed during the growing season, is leveled by autumn rains or during snowmelt [18]. According to the calculation of the contribution of the interaction of factors AB (tillage and fertilization) and $\mathrm{AC}$ (tillage years), it becomes obvious that when sowing barley, there is no priority for some main tillage of dark gray forest soil in the forest-steppe zone of the Trans-Urals. This is because of surface scarification and plowing in the conditions of Western Siberia have a similar effect on weed control and the formation of an optimal airtemperature regime.

\section{Conclusion}

Based on long-term stationary field experiments, it was found that barley yield largely depends on the hydrothermal conditions of the growing season. The sum of positive temperatures, as well as precipitation, have an impact both directly and through other factors (fertilizer efficiency). The use of surface tillage in combination with such a precursor as oat leads to an increase in the variability of barley yield up to $33 \%$. Plowing in combination with peas in the form of a precursor can reduce the variation in yield over the years by up to $16 \%$. The introduction of increasing doses of mineral fertilizers has a positive effect on the harvesting of barley grain and slightly reduces the influence of hydrothermal conditions.

For the period from 2004 to 2014, the maximum yield of Acha barley was $5.57 \mathrm{t} / \mathrm{ha}$ on the variant with a dose of mineral fertilizers $\mathrm{N}_{54} \mathrm{P}_{52} \mathrm{~K}_{52} \mathrm{~kg} / \mathrm{ha}$, which were introduced by plowing. The precursor was oat. The minimum yield was fixed at the level of $1.44 \mathrm{t} / \mathrm{ha}$. In this variant, the precursor was also oat, nevertheless, surface scarification was carried out with a cultivator and no fertilizers were introduced. Such a high efficiency of oat as a precursor, in relation to peas, is explained by the fact that clover was grown in the grain- 
grass crop rotation for two years, the remnants of which, decomposing, enriched the soil with mineral nitrogen for several years. Under the same type of conditions (without perennial legumes), the effectiveness of the precursors of peas and oat may be different.

The share of the contribution of each factor to the formation of barley yield was calculated. The maximum impact was made by the weather conditions of the growing season - 49-72\%; the level of mineral nutrition - $17-25 \%$; the main tillage $-5-6 \%$. Such a high contribution of weather conditions to the formation of barley yield indicates the need to create new ones adapted to the peculiarities of weather conditions in Western Siberia, as well as to develop an adaptive landscape farming system that considers the soil and climatic features of the region. It should be noted that the role of weather conditions increases significantly if to analyze it during critical periods during the barley growing season (tillering, flowering, grain filling).

\section{Acknowledgements}

*The work was performed according to the state task No. 121041600037-3

\section{References}

1. N.V. Abramov, S.A. Semizorov, S.V. Sherstobitov [et al.], IOP Conference Series: Earth and Environmental Science: III International Scientific Conference: AGRITECHIII-2020: Agribusiness, Environmental Engineering and Biotechnologies, (Volgograd, Krasnodar, Krasnodar Science and Technology City Hall of the Russian, 2020)

2. N.V. Abramov, IOP Conference Series: Materials Science and Engineering, 62022 (2019) DOI 10.1088/1757-899X/537/6/062022.

3. E. Demin, D. Eremin, L. Skipin, IOP Conference Series: Earth and Environmental Science, IPDME 2018-Mining Ecology, 092005 (2018), DOI 10.1088/17551315/194/9/092005.

4. D.V. Eremina, D.I. Eremin, IOP Conference Series: Earth and Environmental Science: INTERAGROMASH 2019, 012173 (2019) DOI 10.1088/1755-1315/403/1/012173.

5. A.V. Lyubimova, G.V. Tobolova, D.I. Eremin, I.G. Loskutov, Vavilov Journal of Genetics and Breeding 24 (2), 123-130 (2020) DOI 10.18699/VJ20.607

6. A.V. Chelovechkova, I.V. Komissarova, D.I. Eremin, Journal of Environmental Management and Tourism 9, 3(27), 485-490 (2018) DOI 10.14505/jemt.v9.3(27).08.

7. E.I. Anisimova, A.G. Koshchaev, A.A. Nesterenko [et al.], International Journal of Pharmaceutical Research 10 (4), 604-610 (2018)

8. V. Rzaeva, IOP Conference Series: Earth and Environmental Science, 52079 (2021) DOI 10.1088/1755-1315/677/5/052079

9. D.I. Eremin, V. Eremina, Journal of Environmental Management and Tourism 9, 3(27), 599-604 (2018) DOI 10.14505/jemt.9.3(27).20

10. D. Eremina, MATEC Web of Conferences, 04016 (2018) DOI 10.1051/matecconf/201817004016

11. Y.P. Loginov, A.A. Kazak, L.I. Yakubyshina, Annals of Agri Bio Research 24 (1), 7681 (2019)

12. D.I. Eremin, Eurasian Soil Science 49 (5), 538-545 (2016) DOI $10.1134 / \mathrm{S} 1064229316050033$ 
13. S. Sherstobitov, IOP Conference Series: Materials Science and Engineering, 62011 (2019) DOI 10.1088/1757-899X/537/6/62011.

14. D. Eremin, L. Skipin, MATEC Web of Conferences, 05053 (2018) DOI 10.1051/matecconf/201819305053.

15. P.P. Gonchar-Zaikin, V.G. Chertov, Add-on to EXCEL for statistical evaluation and analysis of the results of field and laboratory experiments, Rational nature management and agricultural production in the southern regions of the Russian Federation, 559-565 (Moscow, Modern Notebooks, 2003)

16. I.D. Svistova, A.Y. Paramonov, N.M. Kuvshinova, K.E. Stekol'nikov, Eurasian Soil Science 49 (2), 194-197 (2016) DOI 10.1134/S1064229316020137.

17. T. Volova, A. Demidenko, S. Baranovsky [et al.], Environmental Science and Pollution Research 28 (1), 982-994 (2021) DOI 10.1007/s11356-020-10359-1

18. D.I. Eremin, O.A. Shakhova, Agrarian Bulletin of the Urals 1(67), 38-40 (2010) 